\title{
Muddled Origins in Picaresque Literature: The Foreshadowing of Chaotic Lives
}

\author{
TERRI SCHROTH \\ BRYANT SMITH
}

\begin{abstract}
Picaresque literature is known for several specific traits: 1) firstperson narration and the protagonist's struggle for survival and a better life; 2) the chaotic childhood, outsiderdom, and low social class of the main character; 3) frequent role changes or disguises; and 4) an inconclusive ending. This article traces the muddled genealogy and subsequent chaotic lives of four pícaros: Lazarillo de Tormes, Quevedo's Pablos de Segovia, Bellow's Augie March, and Defoe's Moll Flanders.
\end{abstract}

Keywords: picaresque, pícaro, Lazarillo de Tormes, Quevedo, Bellow, Augie March, Defoe, Moll Flanders

\section{The Characteristics of a Pícaro}

The strength of picaresque literature lies in its vitality, which is evidenced by its periodic reappearance over centuries; more modern picaresque works add vigor to the genre by not simply reproducing the old form, but by extending and often transforming typical picaresque themes and ideas (Eoff 1956: 190). Several basic themes, following sixteenth-century Spanish paradigms and more specifically Lazarillo de Tormes, lay the foundation of the majority of picaresque narratives. Traits with particular relevance to this article include: 1) first-person narration in which the reader can learn firsthand about the protagonist's quest for the self and struggle for survival and a better life; 2) the protagonist's outsiderdom, alienation, and the absence of his or her father and/or mother; 3) frequent role changes or disguises; and 4) an open ending due to an episodic structure (Pughe 1996: 60). Gasta describes well several characteristics of the narration, the storyline and the narrator's apprenticeship that are common to picaresque literature: 
The adult narrator describes his upbringing and social climbing with biting satire, a critical point of view, and a bittersweet tone [...] the picaresque narrates in episodic fashion the life story of a young boy, orphaned by his mother, and forced to become the apprentice to a series of masters who train the child to survive using cunning and wit in a society that is morally, ethically, and financially bankrupt. (Gasta 2010: 33)

This article traces the birth into a low social class or muddled genealogy, as well as the difficult childhoods of several picaros who represent an array of time periods and national literatures. We will specifically focus on the comparison among protagonists with similar characteristics and life journeys: Lazarillo de Tormes, who was created by an unknown author, Quevedo's Pablos de Segovia, Bellow's Augie March, and Defoe's Moll Flanders. We will attempt to show how their disordered families and childhoods lead to a lifetime of chaos.

To begin with, all four protagonists have a combination of more than one of the following dismal traits of a picaro: an unusual birth, a birth of fate into a low social class, a lack of one or both parents, a tremendous feeling of loneliness and rejection, and a life of chaos that leads to a rogue's career (Yovel 2003: 1315). For example, Lazarillo begins his life with a departure from normalcy, for he is born in a river. In the first two pages of the work, a grown Lázaro reveals the sad details of his family life and childhood to the reader. This type of first-person voyeuristic narration and involved education of the reader is a common trait in picaresque literature (Steinberg 2013: 47) and exists in all four works studied in this article.

\section{Chaotic Childhoods and Family Situations}

When Lazarillo is eight years old, his father is caught "bleeding" sacks of crops at his work and is forced on an expedition against the Moors, where he is killed. His widowed mother moves them to a house in Salamanca, where a Negro stable-man, Zaide, becomes his mother's lover and father to his new mulatto brother. At first, Lazarillo is afraid of him, but afterward adjusts to him, as Zaide always brings (stolen) bread, meat, and firewood home to the family. However, Zaide's thievery, even though it is a means to provide for his new family, leads to his arrest. Lázaro remembers how terrified he was because he had sold horseshoes which were stolen by Zaide; thus, he is taught the ways of picardía early in his life by members of his own family. His mother is once again alone and she decides that giving him up would be the best solution. $\mathrm{He}$ becomes an orphan and is passed off to a blind man, his first of several masters. 
Muddled Origins in Picaresque Literature: The Foreshadowing of Chaotic Lives

When they part, his mother says, “I know I'll never see you again [...] now you must look after yourself'” (Lazarillo ... 2003: 7). In less than four pages into the narrative, Lazarillo, still a boy, has lost connection to his family and is forced to fend for himself.

Much in the same manner, Pablos in El Buscón (The Swindler) narrates the reader through his childhood experiences with family degeneration. His father is a barber and a thief; he trains Pablos' seven-year-old brother to pick his customers' pockets. When the child is caught in the act, he meets a grim penalty: "the little angel died from a few lashes they gave him in prison" (Quevedo 2003: 65). The father only mourns the death of his youngest son because he was an asset, a tool for luring potential victims to rob: "[m]y father was very upset because the child stole the heart of everybody who saw him" (ib. 65). At a young age, Pablos learns from his father that thieving was not a mere job, but a liberal profession and the harsh reality that one who did not steal, would not eat (ib. 66). Therefore, Pablos is never taught good values and has no stable family base. Furthermore, his mother is a witch and is annoyed that her son does not choose to become a male witch. Whitbourn notes that Pablos' background is "of the lowest; his father being a thief who is eventually hanged, and his mother, with Quevedo's characteristic fondness of exaggeration, combining the offices of prostitute, procuress, lesbian and witch" (Whitbourn 1974: 13). Pablos certainly has no positive parental guidance as a youth.

In similar biting picaresque fashion, Defoe's protagonist Moll Flanders enters the world in wretched style. While pregnant with Moll, her mother is sentenced to death for thieving, but successfully "pleads her belly" to gain a reprieve. In yet another unusual birth, Moll is born in Newgate prison and her mother is transported to Virginia shortly thereafter; her father's identity remains unknown. Moll is thus left an orphan and, since England had no House of Orphans as in France, she has to wander around with a tribe of gypsies. At about the age of three, she is taken in by an impoverished gentlewoman, whom she calls "Nurse," who runs a small school. By the tender age of eight, it is time for Moll to enter service, but, luckily, pity is taken upon her and she is allowed to stay with Nurse and make a living doing spinning and needlework. Her one desire, however, is to become a gentlewoman; her dream begins to happen when the Mayor and his family take an interest in her and allow her to be a maid-servant and a semi-adopted daughter in their household. For the time being, Moll enjoys living in a stable environment.

In addition, in Bellow's The Adventures of Augie March, Augie certainly fits the description of a picaroon with his questionable family life and childhood. Like the previous authors of the abovementioned narratives, Bellow allows Augie to make an intimate connection to the reader with first-person narration. 
Augie reveals the dismal memories of his childhood and family life from the very beginning of the narrative:

My own parents were not much to me, though I cared for my mother. She was simple-minded, and what I learned from her was not what she taught, but on the order of object lessons. She didn't have much to teach, poor woman. My brothers and I loved her. I speak for them both; for the elder it is safe enough; for the younger one, Georgie, I have to answer - he was born an idiot. (Bellow 1996: 3)

Augie's mother is not the leader of her family, but rather a follower in the tyranny of Grandma Lausch, an elderly woman who is a boarder in the household as opposed to a veritable grandmother. As for Augie's father, he deserted the family and is only mentioned by necessity. As a child, Augie claims to be able to remember him, recalling his uniform and the possibility of him being a proud soldier. However, his older brother Simon is quick to spoil his illusion by revealing that their father did wear a uniform, but was a driver of a laundry truck. In addition, the family is under surveillance of a caseworker named Lubin and receives assistance from charity.

Like most picaresque characters, the pícaros discussed here lack parental guidance and are forced to seek help outside their immediate families. Parker notes, "[t] he average pícaro is a youth who has never had a chance. Born of disreputable parents, he is forced at an early age to face life without the moral backing that parental care, a normal family life and an adequate education would have given him" (Parker 1947: 60-61). The pícaro's lack of parental supervision and support will forever follow him or her in life - he or she will constantly strive to overcome his or her origins. Ferrán correctly explains the pícaro's lack of nurturing parents and family stability, which leads to an incessant need and lifelong quest to ameliorate the loss and pain felt in childhood:

Hemos aducido la ley del azar y la necesidad-es decir la ley que modernamente parece que condiciona la genética - para enfatizar la falta del padre [y en muchas ocasiones, la de la madre] en nuestros pícaros [...] en la infancia y adolescencia adquiere características que marcarán a nuestros pícaros para siempre.

[...] Su 'weltanschauung' viene condicionada por esta pérdida irreparable, que les deja solos en el camino de la vida... Su vida vendrá marcada por el desamparo, por la rebeldía contra un ciego inclemente, por una continua pregunta sin respuesta, por la desesperación, por la protesta, por el odio... Todo, todo emana de esta ausencia inicial, de esta precoz orfandad [...] soledad. (Ferrán 1979: 57-58) 
Muddled Origins in Picaresque Literature: The Foreshadowing of Chaotic Lives

The pícaro, typically abandoned by his family, receives his education about the harsh world through interaction with various masters. This training in roguery takes place through numerous episodes, or accidents, which begins the journey from the innocence or disillusionment of childhood into the cold bitterness of adult reality.

\section{The Picaro's Education, Search for Identity, and Place in Society}

The next section of this article is dedicated to the discussion of the various aspects of the pícaro's education and his or her journey in search of self-identity and a place in society. Ferrán examines the question of the pícaro's chaotic life and desire for order. In the end, the picaro never has a well-organized plan, only schemes with which to get by or stay afloat. The particular case of Lazarillo's journey and adoption of masters: "[e]l pícaro ve la vida como caos. Poco puede hacer para corregir el torbellino a su alrededor. Pero el azar le lleva yla necesidad le trae, una y otra vez adonde remediarla [...] No hay un plan preestablecido” (Ferrán 1979: 55). After his mother releases him to the blind man, Lazarillo's education about the harshness of life sharply commences when the blind man plays his first trick - the crushing of Lazarillo's head against the stone. Lazarillo is stunned, but learns a great lesson about his situation: "I must keep awake because I'm on my own and I've got to look after myself" (Lazarillo... 2003: 8). Lazarillo experiences aching loneliness, yet trudges on, wandering from master to master. He changes roles along the way, though he never follows a set path or striving for a final destination. With Lazarillo, the reader becomes well acquainted with several motifs which have become fixed in the picaresque tradition, such as being hungry and playing roles. He must revert to playing tricks in order to keep from starving, like waiting to eat at funerals or scoping out the priest's breadbox. When selling water for the chaplain, he is pleased to make a bit of money to buy used clothing; Lazarillo then starts playing the role of nobleman, much like his past master, the squire. The narrative ends without a satisfying resolution to his chaotic life. He has settled down with a job as the town-crier, but his family life remains chaotic. In fact, his discombobulated family life could seemingly continue forever for he marries a woman who has had an affair with their priest. Lazarillo ends up living as a cuckold and seems to be able to live with the "happy arrangement," for he has a roof over his head and food in his belly. The notion of happiness for Lazarillo is simple - survival (food and shelter) takes precedence over supplemental pleasures.

Meanwhile in El Buscón/The Swindler, Pablos, after having his fill of his family's lowly condition, decides that an education may help him rise above 
his origins. He tells his parents that he wants to learn to be an honest man by going to school, thereby showing his childhood belief in good over evil. Pablos receives a roguish education through several unfortunate educational episodes at school. First, he is picked El Rey de Gallos and is bombarded with vegetables. He becomes Don Diego's servant and they both have the bad fortune of going to Dr. Goat's boarding-school, where they are almost starved to death (hunger motif in picaresque literature). For being the new student at the university in Alcalá, he is plastered with slime and phlegm as part of an initiation ritual, which is another important motif of the picaresque. Joseph V. Ricapito notes that even Alcalá, the seat of the great university, is shown as a place of chaos and mayhem rather than an important site for learning (Ricapito 1985: 157). In this instance, Don Diego serves as Pablos' master and gives him a wake-up call about his family situation and life: "Pablos, you've got to wake up. Watch out for yourself. You know your father and mother can't do it for you'" (Quevedo 2003: 88).

Pablos has by no means escaped his low genealogy and family ties to the past. While Pablos is away studying at university, he receives a letter from his uncle announcing the death of his father. Pablos naively thinks that his uncle is "a very virtuous man and well known in Segovia for his passion for justice," (ib. 100) for he is a hangman. His uncle states with certainty that his father was hanged and died with dignity: "That I can guarantee as I topped him myself'” (ib.). His uncle, his own father's executioner, is ludicrously proud to have "'quartered him and buried his remains along the roads" (ib. 101). Again, what his family sees as a sign of pride makes Pablos recoil with shame and disgust.

The unpleasant family news continues, as his uncle bluntly recounts the wretched activities of Pablos' mother:

'Your mother is still alive, but she might just as well not be, because the Toledo Inquisition has got her for digging up the dead, literally, not just for talking about them. They say she kissed the billy-goat's arse every night. They found more legs, arms and heads in her house than in a miraculous shrine, and the least she did was to fake virgins.' (Ib.)

As a result of such scandal, Don Diego is ordered by his father to leave Alcalá without Pablos. After feeling some sense of belonging and companionship, Pablos is saddened "to leave the best life I had ever had" (ib. 103). Just as he is getting settled, he is forced to move onto yet another episode in his chaotic life, driving home his sentiment, "because it's one damn thing after another" (ib. 88). Now alone, Pablos leaves the university in search of his uncle in order to claim his inheritance. 
Muddled Origins in Picaresque Literature: The Foreshadowing of Chaotic Lives

Pablos' unpleasant reentry to Segovia is described brilliantly by Quevedo: [Pablos] "saw [his] father waiting for [him] by the road - in quarters of course." What a horrible thought when returning to one's hometown and family! Pablos is utterly disgusted by his uncle and only cares to collect his money and leave: "I got away from him, feeling so ashamed that, if I hadn't depended on him to get my legacy, I would never have spoken to him nor gone anywhere near him in my life" (ib. 121). After his inheritance is settled, Pablos seals a letter to his uncle telling him that he never wants to see him again, in hopes of clearing himself of any family ties.

Next, Pablos tries to rid himself of his past and start anew in Madrid: "'there are some people there, me for example, that you don't know anything about, where they came from or who they are. We've all got different names'” (ib. 132). Parker provides a thorough discussion of Pablos' desire, yet inability, to "negar la sangre:"

[I]t is "precisely 'la sangre' that makes his ambition an impossible one. He cannot consort with the upper classes on terms of equality, for he has neither birth nor wealth. [...] Pablos's ambition leads him into a life of roguery [...] the extravagance of his ambition is his undoing [attempting to marry an heiress] [...] His foolish and arrogant endeavour to 'negar la sangre' recoils upon him. (Ib. 66)

Parker is of course referring to the demise of Pablos' fraudulent identity - in order to marry into money and social position, he plays the role of a gentleman from a higher class, only to be exposed by his old master Don Diego.

Pablos' final resolution is to go to the New World and start afresh yet again, but he gives the reader a sense of how that turns out: "[it] went worse, as [it] always will for anybody who thinks he only has to move dwelling without changing his life or ways" (ib. 197). Therefore, no matter what he does or how he schemes, he never seems to "negar la sangre" (Eoff 1956: 191-192). Ricapito echoes this idea of the inescapability of one's origins: "Pablos never leaves the moral - or immoral - atmosphere into which he is born. Every effort at bettering himself meets with failure. Pablos, at the end of his life's odyssey, is just as much a social outcast as he was in the beginning" (Ricapito 1985: 160). Therefore, the conclusion of El Buscón is clearly picaresque - the protagonist is not settled, and although he may have learned a bit about life, he does not resolve any issues or improve his social mobility.

Meanwhile, while living with the Mayor's family, Moll Flanders experiences her dream of being a gentlewoman in training and enjoys many privileges, such as learning the same cultured lessons in French and dance as the daughters of 
the house. Although she is first a secret lover to the family's oldest son, Moll ends up reluctantly marrying the younger son, for he is truly in love with her and can provide a good home. However, Moll is not allowed to forget her low parentage - the Mayoress avariciously opposes the marriage, for she wants to prevent her son from marrying a nobody who would not enhance the family fortune. Moll lives as the younger son's wife until his death a few years later. The two children from their marriage are virtually purchased by the Mayor and his wife, leaving Moll a rather attractive widow, both financially and in terms of beauty, for she is still young.

At this point, however, Moll's life takes a tailspin into chaos: she marries again and goes bankrupt; she marries yet again and moves to Virginia, only to find out that she can never escape her chaotic parentage. She has in fact married and had children with her brother, meaning that her mother-in-law was her very own mother. Maurice Molho points out la déterminabilité négative in Moll Flanders (Molho 1984 : 143). Since Moll's father is unknown, he is negative (le père incertain est un père négatif) (ib.). Molho affirms that Moll's older brother could serve as a paternal image, or a substitution for her lost father: "un curieux retournement du roman familial, par substitution à l'image paternelle de celle du frère aîné, voué dès lors à fonctionner comme substitut œdipien du Père" (ib.). Therefore, the cycle of chaos and family disorder continues; Moll's son is created as a result of incest, the ultimate degradation of family genes.

Moll returns to England and nothing improves. She ends up pregnant by her latest husband and gives the baby away, pushing her total number of abandoned children to four. She is able to establish glimpses of happiness here and there, but ends up a widow. Left nearly penniless and no longer young enough to attract a young husband, Moll turns to a life of crime. She very quickly loses her fear of conscience and becomes a skilled swindler.

Like Lazarillo, Pablos, and Augie, Moll recounts her many adventures and episodes of roguery. However, her narrative concludes in a different manner by providing a happy ending, which breaks from the picaresque tradition. Although she is essentially born an orphan, she survives her chaotic childhood and frenzied life of incest, several marriages, and prison; she is the only protagonist to come out ahead of her origins. After she is arrested for her crimes of thievery and sent to Newgate prison, ironically where she was born and left an orphan, she begs for transportation to Virginia and is granted her wish, just as her mother. In the end, she rekindles her love with her Lancashire husband and reconciles with her son in Virginia. In fact, Moll and her husband become quite wealthy from their Virginian plantation. They eventually move back to England and happily end their days there. 
Muddled Origins in Picaresque Literature: The Foreshadowing of Chaotic Lives

As alluded to earlier, Augie March's first adventures in picardía come from Grandma Lausch. In order to get glasses from the Charity, Augie is coached by Grandma on how to lie. Augie is the lead liar and even speaks for his simpleminded mother. Grandma tells Augie's mother, "'Remember, Rebecca, let him answer everything [...] You keep out of it. If they ask you something, you look at Augie like this;" and to Augie, she says, "When they ask you, 'Where is your father?' you say, 'I don't know where, Miss”" (Bellow 1996: 8). Although Grandma Lausch controls Mama and seems harsh with the children, she does provide insight into the workings of the outside world and "put a regulating hand on the family life" (ib. 10). In fact, Grandma brings Simon and Augie an encyclopedia set and encourages them to continue with school.

Augie remembers being "farmed out" to work at an early age. During the summer when he is about twelve years old, he moves to the North Side of Chicago to work. Augie, as well as his brother Simon, are faced with taking on the role of household male breadwinner and are responsible for supporting their fatherless family, intellectually challenged mother, and handicapped brother. When Augie, a mere teenager, is fired from one of his many jobs, he is read the riot act by Grandma:

Seemingly the old lady had been waiting for just this to happen and had it ready to tell me that there were faults I couldn't afford to have, situated where I was in life, a child of an abandoned family with no father to keep me out of trouble, nobody but two women, feeble-handed, who couldn't forever hold a cover over us form hunger, misery, crime, and the wrath of the world. (Ib. 36)

As a result of his childhood jobs and Grandma Lausch's severity, Augie learns how to fend for himself and quickly begins to realize the ways of the world.

In true picaro fashion, Augie receives his education from various sources. Besides Grandma and a rather large list of bosses and ruffians, Mrs. Renling makes a serious attempt to refine him, registering him for evening courses at Northwestern. However, the idea is not to allow Augie to grow as an independent individual, but rather to make him follow her rules. In addressing Augie, Mrs. Renling said, "I'll make you perfect [...] completely perfect"” (ib. 130). He is given the best clothes, the highest of educations, and accompanies Mrs. Renling on trips to learn refinement.

Augie takes on his role as a wealthy young man with curiosity and pride. Like picaros, he begins to put up a front and disguise himself in superior roles. When he escorts Mrs. Renling to the prestigious Merritt Hotel on the lakeshore in Michigan, for example, he pretends that the swanky vehicle he is parking 
is indeed his own, rather than the Renlings'. He ends up cleverly schmoozing with the Fenchel sisters' uncle.

However, after some time Augie shows his unwillingness to fully comply. He feels too confined by the hold of Mrs. Renling and completely rejects the idea of adopting a new identity: “[j] ust when Mrs. Renling's construction around me was nearly complete, I shoved off. The leading and precipitating reason was that she proposed to adopt me. I was supposed to become Augie Renling, live with them, and inherit their dough" (ib. 151). Mr. Renling is willing to be a father to Augie, but Augie will have no part in it. He has lived his entire live with the absence of a father or male figure and finds it quite suffocating to accept one at that point in his life. When she learns the truth, Mrs. Renling is furious with Augie and calls him a child of fools. Once again, Augie is unable to escape the mention of his genealogy.

In this case, Augie's actions are both picaresque and non-picaresque. By refusing immediate wealth, the good life presented to him on a silver platter, and a large inheritance, he shows the reader his non-picaresque side. He may not exactly know where he is going or who he is, but he knows he has a family, although it is not the richest or most stable. He certainly knows he is not Augie Renling. Augie rejects the idea of recreating himself as a Renling and decides to seek his own identity. After Augie decides abruptly to leave the Renlings, he jumps from job to job, from scheme to scheme. He becomes involved with smuggling immigrants into the United States, hitch-hikes halfway across the country, jumps trains, and crawls under tarps on trucks for means of transportation. Adding to the picaresque element of the narrative, a tired and filthy Augie makes a few buddies and scrounges up some meager rations of bread, peanut butter, and milk. He even gets arrested on a bogus charge of stealing car parts.

Meanwhile, Augie's family is not having any luck. Mama has been kicked out of her house and is living downstairs with the neighbors; Grandma has died. Simon, who has been in jail, does not have enough money to keep the house and the furniture, so he has to put his own mother out of a home. Augie realizes that their family problems are no longer in hiding: " $[\mathrm{t}] \mathrm{ill}$ now, as a family, we had had some privacy, even if it was known that we were deserted as kids and on Charity. In Grandma's time nobody, not even the caseworker Lubin, was informed exactly about us [...] Now there were no secrets, so anybody interested could look" (ib. 182). Their imperfect family would forever haunt them. In fact, it is about to be examined under a microscope with Simon's marriage into the wealthy Magnus family.

At this point of the novel, as well as many others, it is appropriate to discuss Simon's traits as a picaro. After being spurned by the marriage of his ex-fiancée 
Muddled Origins in Picaresque Literature: The Foreshadowing of Chaotic Lives

Cissy and falling upon hard economic times, Simon goes into marriage specifically looking for money. When he meets Charlotte's family, he puts on a big act and almost becomes an entirely different person. As a true picaro, he alters his behavior and plays the necessary role in order to impress them. Simon enlightens Augie on the difference between their family and Charlotte's. In complementing the Magnus family, Simon puts down his and admits that he has become one of them:

'[Y] ou can see how unlucky we were not to have this kind of close and loyal family. There isn't anything these people won't do for one another. We don't even understand what this is because we never experienced it, we missed it all our lives. We had no luck. Now they've taken me in and made me one of them, as if I were their own child. I never understood what real family was till now, and you ought to know how grateful I am.' (Ib. 217)

Augie is repulsed by these statements; he hates what Simon has become. Augie wants to defend their family and begins to realize that he has little to defend. He is willing to play Simon's game for his brother's benefit, but resists buying into the complete defamation of his family. Simon forces Augie to go along with the scheme to impress the family: "Simon had himself steamed and singed, manicured, everything lavished on himself, and not simply urged me but forced me to do as he did. He wanted to try all they knew how to do" (ib. 223). It is important to note that further on in the story, Simon sets up Lucy Magnus, Charlotte's sister, with Augie. Just as with the Renlings, Augie has a perfect path to wealth set in front of him: "[a]11 I had to do was play along, make myself desired, interpret, as I could do, the role of the son-in-law her parents wanted" (ib. 239). These episodes of masquerade also display the appearance versus reality motif of the picaresque.

Simon's worry about his family's appearance reaches its highest peak at his wedding to Charlotte. He is not the slightest bit concerned with the happiness or comfort level of his blind mother, but rather how she would look to the Magnuses. After fretting for Mama to wear glasses, with which she complies with obedience, he becomes frantic that she has brought her white cane, which would appear shamelessly in the wedding pictures. When Cousin Anna mutters something to Simon in Mama's defense, he has the audacity to say, "You shut up, you cow!" (ib. 241). Simon is disgusted with his family and shows his embarrassment by stating, "What a turnout on our side!" (ib.).

As for Augie, he declares his deep love for Thea Fenchel. Unlike most pícaros, he makes a serious effort to form a "normal" relationship: "I tried to tell her that I had looked all my life for the right thing to do, for a fate good enough, 
SCHROTH, SMITH

that I had opposed people in what they wanted to make of me, but now that I was in love with her I understood much better what I myself wanted" (ib. 318). In this citation, one can also identify another motif of picaresque literature the search for order and direction. Augie admits that he has tried to discover his true path in life, and with Thea's presence, he has learned more about what he wants, veering a bit from the cunning picaro by trying to do the right thing. It should be noted that Augie is criticized by Thea for his (non-picaresque) goodness of heart: “'Oh, you screwball! You get human affection mixed up with everything, like a savage. Keep your silly feelings to yourself”” (ib. 347).

Toward the end of the narrative, however, the reader can clearly observe that Augie has grown up. After all his adventures as a youth, from his escapades in Mexico to his time in the military, he expresses the desire, yet inability, to live a more traditional, settled life: "I would have preferred to stay in the States and have children. Instead I'm in the bondage of strangeness for a time still. It's only temporary. We'll get out of it" (ib. 523). While living in Europe with Stella, he is unable to settle down, but as usual, sees it as a short-term situation and looks immediately to changes in the future. Finally, at the conclusion of the narrative, Augie makes one concluding statement about his chaotic life and desire for order: "It must be clear, however, that I am a person of hope, and now my hopes have settled themselves upon children and a settled life. I haven't been able to convince Stella as yet" (ib. 529).

\section{The Picaresque Ending}

The chaotic plot of most picaresque narratives comes to a disorganized or openended finish. Augie and Pablos remain unsettled at their conclusion; Lazarillo is settled but living as a cuckold; and Moll seems to be the only picaroon to pull order out of her chaotic life and conclude relatively happily. The longestablished picaresque ending can be seen as a reflection of the pícaro's chaotic life. Since the picaresque narrative "does not give a structured vision of life [and focuses] on details, surfaces, on fragments, and on discontinuous and fleeting experiences and reactions," it is only fitting that the conclusion remains openended (Wicks 1989: 246).

In conclusion, certain elements of the chaotic nature of picaresque literature are exhibited clearly through the characters of Lazarillo de Tormes, Pablos de Segovia, Moll Flanders, and Augie March. We have provided an extensive list of examples to show how the muddled genealogy of a picaroon foreshadows chaos in life. Certainly, the main picaresque traits that contribute to this chaos are the birth into a low social status and inescapable genealogy 
Muddled Origins in Picaresque Literature: The Foreshadowing of Chaotic Lives

of the picaro, the first-person narration of random or fragmented episodes of the picaro's life, and the education that transpires by following several masters and by playing an assortment of roles. The only picaroon who is able to lift herself out of her social status is Moll Flanders, but she does not escape the journey without a great deal anguish, hardship, and swindling. Furthermore, the protagonists included here fit many of the traits of the "curriculum vitae" of the typical pícaro (casualidad, hambre, malos tratos, mixta, mendicante, etc.) (Cañedo 2007: 350). The works studied in this article traverse national borders and languages, and represent different time periods of the picaresque, yet they exemplify several common traits among all works in the picaresque tradition, as well as the creative variations by individual authors.

\author{
Terri Schroth, PhD \\ tschroth@aurora.edu \\ Aurora University \\ 347 S. Gladstone Ave. \\ Department of Foreign Language \\ Institute 123 \\ Aurora, IL 60506 \\ USA \\ Bryant Smith, PhD \\ james.smith@nicholls.edu \\ Nicholls State University \\ Department of Languages and Literature \\ PO Box 2023 \\ Thibodaux, LA 70310 \\ USA
}

\title{
References
}

Bellow, S. 1996. The Adventures of Augie March. New York: Penguin.

Cañedo, J. 2007. El 'Curriculum Vitae' del Pícaro. - RILCE Revista de Filología Hispánica, 23.2, 350-396.

Defoe, D. 1989. Moll Flanders. Ed. David Blewett. London: Penguin Classics.

Eoff, S. 1956. Tragedy of the Unwanted Person, in Three Versions: Pablos de Segovia, Pito Pérez, Pascual Duarte. - Hispania, 39, 190-196.

Ferrán, J. 1979. Algunas constantes en la picaresca. - La Picaresca: Origenes, Textos y Estructuras. Ed. Manuel Criado de Val. Madrid: Fundación Universitaria Española, 53-62.

Gasta, C. 2010. The Picaresque According to Cervantes. - Philological Quarterly, $89.1,31-53$. 
SCHROTH, SMITH

Lazarillo de Tormes. 2003. Ed. and trans. Michael Alpert. $2^{\text {nd }}$ ed. New York: Penguin.

Molho, M. 1984. Le roman familial du pícaro. - F. Gewecke, ed., Estudios de literatura española y francesa: Siglos XVI y XVII, Homenaje a Horst Baader. Barcelona: Hogar del Libro, 141-148.

Parker, A. A. 1947. The Psychology of the 'Pícaro' in 'El Buscón.' - Modern Language Review, 42, 58-69.

Pughe, T. 1996. Reading the Picaresque: Mark Twain's The Adventures of Huckleberry Finn, Saul Bellow's The Adventures of Augie March, and More Recent Adventures. - English Studies, 77.1, 59-69.

Quevedo, F. de. 2003. The Swindler. Ed. and trans. Michael Alpert. $2^{\text {nd }}$ ed. New York: Penguin.

Ricapito, J. V. 1985. Quevedo's Buscón - 'Libro de entretenimiento' or 'Libro des desengaño’: An Overview. - Kentucky Romance Quarterly, 32, 153-164.

Steinberg, S. 2013. Originary Debt (1816). - Revista Hispánica Moderna, 66.1, 43-56.

Whitbourn, Ch. J. 1974. Moral Ambiguity in the Spanish Picaresque Tradition. - Ch. J. Whitbourn, ed., Knaves and Swindlers. London: Oxford UP, 1-24.

Wicks, U. 1989. Picaresque Narrative, Picaresque Fictions: A Theory and Research Guide. New York: Green Wood Press.

Yovel, Y. 2003. The Birth of the Picaro from the Death of Shame. - Social Research, $70.4,1297-1326$. 